\title{
The paradox of victory: social movement fields, adverse outcomes, and social movement success
}

\author{
Bert Useem $^{1}$ (D) Jack A. Goldstone ${ }^{2}$
}

Accepted: 8 September 2021 / Published online: 2 October 2021

(c) The Author(s) 2021

\begin{abstract}
Recent work on social movement fields has expanded our view of the dynamics of social movements; it should also expand our thinking about social movement success. Such a broader view reveals a paradox: social movements often snatch defeat from the jaws of victory by narrowly targeting authorities with their actions instead of targeting the broader social movement field. Negative impacts from the wider social movement field can then reverse or overshadow initial victories. We distinguish between a social movement's victory over the immediate target, and more lasting success that arises from shifting alignments in the broader social movement field. To test the predictive value of the distinction, we compare two very similar student-led social movements, both of which targeted university policies regarding sensitivity to race issues and changes in university personnel. One built a broad coalition of support that extended across its social movement field and was thereby able to institute durable change. The other did not, and despite its clear initial success, this protest movement produced consequences mainly adverse to its preferred outcomes. We demonstrate how pervasive this paradox is with examples from other U.S. protest outcomes and studies of revolutions. The paradox is resolved by focusing on changes in the entire social movement field. We thus argue that achieving, and understanding, lasting social movement success requires attention to the entire social movement field.
\end{abstract}

Keywords Social movements $\cdot$ Fields $\cdot$ Durable change $\cdot$ Victory $\cdot$ Success

Bert Useem

buseem@purdue.edu

Jack A. Goldstone

jgoldsto@gmu.edu

1 Department of Sociology, Purdue University, West Lafayette, IN 47907, USA

2 Center for the Study of Social Change, Institutions and Policy, Schar School of Policy and Government, George Mason University, 3351 Fairfax Drive, 5th Floor, MS 3B, Arlington, VA 22201, USA 


\section{Introduction}

Social movements operate in a complex environment. As many researchers have noted, this makes analysis of movement outcomes challenging. More than four decades ago, William Gamson (1975) analyzed social movement success mainly in terms of whether social protest groups won advantages that they sought, and framed the reasons for success in terms of their organization and tactics. Other scholars have expanded the definition of success to include acceptance of the protest group as regular members of the polity (Tilly, 1978), or shifting the policy-making agenda (Swarts, 2003).

Yet how much of policy change is directly attributable to a protest group's actions, as opposed to circumstances, or other social actors, or broader cultural or political shifts, is often difficult to trace. Goldstone (1980) demonstrated, using Gamson's own data, that larger historical circumstances more strongly predicted group success than the actions of the protest group. Moreover, lasting success is often elusive, even if a group achieves initial victories. If we look back on some of the social movements that by Gamson's definition would clearly have enjoyed success, by achieving desired policy changes, we see paradoxes in current conditions. For example, the U.S. civil rights movement obtained two notable successes ensconced in landmark legislation and policy change: desegregation laws for school systems and anti-discrimination laws for housing. Nonetheless, decades later we find that major school systems remain, in practice, largely segregated, ${ }^{1}$ while residential patterns in many major U.S. cities still show "hypersegregation."2

In this paper, we seek to explain how social movements can fail to achieve their broader goals despite-or even because of - their achievement of what is conventionally hailed as a movement success. We develop our analysis in three steps: First, in regard to social movement theory, we argue that studies of social movement contestation must shift from the typical dyadic view, which highlights social movement/ target interactions, to the newer approach of analyzing movement dynamics through social movement fields. Using this field perspective, we define movement success not in terms of changing the policies or the behavior of the movement's target-outcomes such as policy changes, replacement of target personnel, or changing the relations between challengers and authorities, all of which we label movement "victories"-but in terms of changing the alignment of the broader social movement field.

Second, in regard to empirical analysis of movement outcomes, we believe that social movement scholars, in their effort to broaden their appreciation for the range of social movement outcomes, have tended to define movement success either too

\footnotetext{
${ }^{1}$ In the Los Angeles Unified School District, "more than half of the students ... attend a school that's more than 90 percent black and Latino" (Stokes 2018); in New York City, the "public schools remain among the most segregated in the nation" (Shapiro 2019). For all of New York State, a UCLA report identified extreme segregation in school districts throughout the state (Kucsera and Orfield, 2014).

$2{ }^{2}$ Although the number of U.S. cities showing hypersegregation has declined over the last three decades, "the degree of segregation within those areas characterized by hypersegregation changes very little. As of 2010, roughly one-third of all black metropolitan residents lived in a hypersegregated area" (Massey and Tannen 2015: 1025).
} 
narrowly-as changing the behavior or power of targeted authorities or achieving preferred policy outcomes or collective benefits-or too broadly-as bringing "unintended consequences" or "systemic changes" to the entire political and/ or cultural system. We suggest that our proposed definition of success-achieving a favorable realignment of the social movement field that impacts that movementoffers an intermediate approach that embraces these perspectives, but is a more useful and empirically accurate way to analyze movement success and frame diverse outcomes.

Third, in an analysis of two exemplary cases, and in a number of additional examples, we demonstrate the value of this approach by showing how the interactions between a social movement and its wider social movement field can lead to a variety of positive or adverse and even paradoxical outcomes. This helps us to identify specific patterns of interaction that yield lasting success, or that invite paradoxes of initial striking victories followed by marked setbacks, reversals, or erosion of movement gains.

We find that where a social movement's actions are framed to attract support from a variety of actors in the social movement field-potential allies, countermovements, the public, and multiple actors in positions of authority-and shift the field alignment by creating a stable new consensus among multiple key actors, such that the movement and its goals become embedded in the new status quo, then success is likely to last. Conversely, if the social movement's actions polarize the social movement field, creating enmity and/or opposition among a variety of actors in the wider field, then even if the movement obtains a policy change or formal policy access from its specific target, then that success is unlikely to last. Indeed, polarization in the social movement field will often be followed by actions that undermine or reverse the social movement's initial gains, and can lead to wider social changes that leave the social movement's supporters worse off than before. Thus, a social movement can attain a clear victory in terms of achieving a change in policy and gaining collective benefits, yet still have further consequences that entail succeeding reversals. We do not argue that it is necessary to transform the entire political or cultural system of society at large to achieve lasting success; that takes us to the subject of revolution (which we revisit below). What we suggest is necessary for lasting success is that a favorable shift in the movement's social-movement field occurs that becomes embedded in the broader social system.

Social movements and social movement fields.

Social theorists have long pointed to the potential for advancing social analysis by deploying Pierre Bourdieu's concept of "fields" (Swartz, 1998, 2013; Martin, 2003). For Bourdieu, social life was not simply regulated by norms, nor by individual choices; rather the competition and cooperation among individuals took place in fields of interaction whose development shaped interpersonal relations. The concept of fields was then applied to relations among organizations by DiMaggio and Powell (1983). However, the adoption of a social field perspective has been late in coming to analysis social movements.

Much of the scholarship on social movements that examines their outcomes has done so primarily from a dyadic perspective, seeing social movements' actions and aims as drawing on cognitive dissonance and social networks to mobilize supporters 
against a target, framing their goals in terms of changing the target's behavior in order to achieve justice or meet social needs, and taking advantage of political opportunities that render the target vulnerable to influence by protest campaigns (McAdam, 1996, 1998; Amenta \& Young, 1999; Tilly, 1999; Benford \& Snow, 2000; McAdam et al., 2001; Burstein \& Linton, 2002; Meyer, 2004; Amenta, 2006; Amenta et al., 2010; Tarrow, 2011; Almeida, 2019). This emphasis on analyzing how and whether movements have managed to mobilize and act to influence their target has been labelled "movement-centered" analysis (Amenta, 2014), and such dynamics have been summarized as "challenger-incumbent" contests (Rojas \& King, 2018).

The development of a "social movement fields" alternative has arisen in response to the limits of such "challenger-incumbent" framing, and the criticism of "movement-centered" analysis as too narrow a view of movement dynamics (Amenta, 2014). For example, Amenta's (2006) study of the Townsend movement showed that even though the government did not adopt its specific Townsend Plan, the movement nonetheless had significant social impacts, as its efforts shaped the debate on social security and secured the provision of U.S. government pensions. As Beland (2007, p. 66) notes in his review of Amenta, "Scholars should look at the broad and often unanticipated consequences of movements instead of assessing the "success' of social movement organizations by comparing their official goals with their achievements." Meyer (2003, p. 35) has showed us that "the seemingly permanent establishment of 'movement organizations' in Washington D.C. and in state capitals across the United States has-even if these groups often lose-fundamentally changed policy-making." Similarly, Armstrong and Bernstein (2008, p. 87) have argued for a "Multi-Institutional Politics" approach, where instead of targeting specific authorities, "movements may target a diverse array of institutions (both state and nonstate)." All of these revisions in describing social movement outcomes are, in essence, describing changes in the social movement field.

An explicit social movement field analysis of movements has been offered by Goldstone (2004, 2015) and most fully developed by Fligstein and McAdam (2012). In these analyses and others, scholars have suggested that instead of focusing on challenger-authority dynamics, social movement actions be viewed as taking place in a broader social movement field, which includes not only the movement and its target, but also active and potential counter-movements, active and potential coalition partners, the broader public, and other organizations and actors who, though not the target of the movement, would be affected by the movement's actions and goals (Goldstone, 2004, 2015; Chen, 2009; Luders, 2010; Goldstone \& Useem, 2012; Fligstein \& McAdam, 2012; McAdam \& Boudet, 2012; Crossley \& Diani, 2018; Rojas \& King, 2018).

To be sure, there is no single model of social movement fields. Fligstein and McAdam's (2012) presentation of social fields tends to draw on the "challengerincumbent" relationship, only multiplying the number of challengers and incumbents and treating social movement outcomes as shifting the position of some challenger at the expense of some incumbent. While recognizing their key contribution, we here follow the more critical approach of Goldstone and Useem (2012), Rojas and King (2018), and Goldstone (2015), in which the movement and its target are 
both engaged in competing, in Bourdieu-type fashion, to reshape the wider social movement field in which they are engaged by changing multiple relationships in order to preserve, change or restore a particular field equilibrium, rather than simply shifting the positions of particular challengers or incumbents.

We wish to point out that there are interesting implications of this shift in perspective for treating the outcomes of social movements. We believe that many of these implications have not been made explicit, and that if we do not escape from treating movement outcomes in the "challenger-incumbent" view, we will stumble in seeking to explain paradoxical results and will misidentify actual outcomes.

To be sure, generations of scholars have recognized that a protest movement's success is dependent not only on its interactions with its target, but on interactions with the broader public, prevailing institutions, and wider social change. Snow et al. (1998) have argued that social disruptions or crises are often key to social mobilization, while Goldstone (1980) long ago argued that major social crises produced clusters of social movement success. Skrentny (2004), Amenta (2006), Chen (2009) and Van Dyke and Amos (2017) are among the best of many studies that show how national party alignments and coalitions with allies are crucial to movement success. Banaszak and Ondercin (2016) demonstrate the crucial role of shifting public opinion to movement outcomes.

Social movement analysts have also shown how actions by actors in the wider social movement field can shape movement failures. Mottl (1980), Zald and Useem (1987), Meyer and Staggenborg (1996), and Burrel (2018) have noted that movement success may be frustrated or altered by countermovements. McVeigh et al. (2004) argued that the $\mathrm{Ku}$ Klux Klan, despite considerable success in mobilizing supporters in the U.S. in the early twentieth century, may nonetheless have hurt the chances of its preferred candidate for president in 1924 because of the negative associations the Klan provoked with the broader public. Snow and Soule (2010) pointed out that social protest movements can provoke repression and countermobilization that block or alter a movement's progress. Amenta et al., (2010, p. 290) have even noted that unsuccessful challengers can do "worse than fail" by inducing more severe repression of their members. Recently, Vann (2018) found that, in the 2010 mid-term election for US Senate, counties with more numerous Tea Party rallies had higher levels of voter turnout for Democratic candidates. Movement mobilization produced voter countermobilization.

Today most studies of movement outcomes have moved beyond Gamson's and Tilly's notions of success as winning specific group benefits, or formal group recognition, from targeted authorities, and now ask whether a movement has contributed to political changes or collective benefits that reflected the movement's goals (Amenta et al., 2010). They may also treat success as a recursive process, in which a movement succeeds by initially gaining allies or leverage through gains with political parties or leaders, and then gradually uses that leverage to subsequently achieve policy gains.

We therefore argue that the time has come to formalize all of these findings by embracing the theoretical view that social movement-target dynamics are fully embedded in social movement fields that must be analyzed as a whole, and thus that social movement outcomes cannot be understood without analysis of how 
the movement field as a whole has changed. We then can specify that while policy and relational shifts may represent victories over a particular target authority, only changing the alignments in that field to produce a new, stable, and favorable equilibrium can bring lasting success.

Such a shift in alignments may in some cases, but usually does not, involve structural change at the societal level. Marco Giugni (1999, p. xxiii) has suggested that "protest can produce political changes in three ways: by altering the power relations between challengers and authorities; by forcing policy change; and by provoking broader and usually more durable systemic changes, both on the structural and cultural levels." Kriesi and Wisler (1999, p. 43) echo this view by stating that "Institutional change implies a paradigmatic shift regarding the political system. Such a shift occurs only in periods of profound social crisis." We think the degree and scale of such change is variable; change on a systemic level may be involved in national reform campaigns, but most social movements seek more circumscribed goals, focusing on a particular policy domain, and thus have a social movement field that can shift alignment without such paradigmatic shifts or systemic structural/cultural change. Instead, this shift involves a new equilibrium among a set of actors and institutions germane to that particular movement, such that the new equilibrium relations become embedded in the local social structure of that particular movement/policy domain. This implies that one of the key empirical tasks of the social movement analyst is to identify the precise social movement field of the specific movement being studied (Goldstone, 2015).

We show below how the success of a movement in changing the behavior of their targets or in achieving policy goals, or elevating the standing or influence of the movements' supporters, may be associated with quite different changes in the social movement field. In some cases, new relationships may be forged that help cement the desired outcome. But in other cases, the very act of achieving local victories may have ripple or lagged effects on other actors in the social movement field that lead those other actors to behave in ways that create adverse outcomes for the successful movement, sometimes making things even worse than before.

Thus, rather than see social movement dynamics primarily as a struggle by movements to change the behavior of their targets, allowing for the secondary role of context, coalitions, and counter-movements, we propose that social movement dynamics should always be seen as an interaction between movements, their targets, and other actors and institutions comprising a social movement field, which triggers reactions and reconfigurations in that field. It is then the new configuration of the social movement field as a whole, rather than just changes in the behavior of the target, that should be the basis for analyzing movement outcomes.

To be sure, most scholars of social movements recognize the crucial importance of context to movement outcomes; many may even consider it obvious that immediate victories can lead to future setbacks. Yet the theory of social movements still typically focuses the definition of movement success on changing the composition or behavior of targets to achieve a favorable policy. Thus, Paul Almeida (2019, p. 121), in a new textbook on social movements, writes that "Outcomes range from total failure and movement collapse to movement victories in 
the form of new favorable policies, such as the legalization of gay marriage or the popular ousting of an authoritarian government."

\section{Applying social movement field theory}

We can summarize our argument by contrasting it with the widely adopted political opportunity structure (POS) theory of social movement dynamics (McAdam, 1996; Tarrow, 2011). We highlight the different empirical features that one is led to focus on by the theoretical approaches. Figure 1 illustrates how different conditions are entailed in achieving a victory vs. attaining lasting success.

There are changes in the required conditions for all aspects of the POS model: framing, mobilization, and political opportunities. For example, regarding mobilization, it is possible for a social movement to achieve what Charles Tilly (2006; Wouters \& Walgrave, 2017) labelled being sufficiently WUNC (appearing Worthy, United, Numerous, and Committed) to wear down opposition and win a victory, while at the same time alienating or provoking opposition outside the target group that has adverse effects on either the target institution or the policies that were enacted. In contrast, as the work of Chenoweth and Stephan (2011) on revolutions and civil resistance has demonstrated, non-violent tactics that aim to win sympathy and support from the wider public, and undermine the legitimacy of the movement's

\section{VICTORY}

Framing "Cognitive Liberation" and creation of a narrative sufficient to energize and mobilize a minimal winning coalition to support the movement

Mobilization Mobilizes sufficient actors to undertake protests and institutional actions that are large enough in volume and sustained in time to overcome resistance of the target (WUNC)

\footnotetext{
Political Takes advantage of divisions within Opportunity the target group/institutions and their defenders that weaken repression and allow construction of a minimal winning coalition with key elites
}

\begin{abstract}
SUCCESS
Creation and diffusion of a narrative sufficient to win over wider publics and weaken opposition narratives, leading to the movement view becoming embedded in a positive frame in mainstream political views.

Mobilizes in a way that does not provoke and energize countermovements and counter-elites; rather wins sympathy and support of wider, but non-mobilized publics and key elites
\end{abstract}

Takes advantage of wider social or cultural shifts that enable the movement to win over wider publics, and weaken or marginalize opposition but without severely weakening or undermining the institutions that are the target of changing policy and necessary for implementing it.

Fig. 1 Victory versus success for social movements 
target, are much more likely to produce lasting success than violent assaults on the targeted authorities, even if those assaults are initially effective.

To further illustrate the merits of a field approach, in the remainder of this essay we analyze an empirical problem: How did a pair of very similar social movements in similar settings in the United States, that used similar tactics to achieve similar local victories, produce very different longer-term outcomes and costs/benefits for the movement actors? Our cases are both movements in which student protesters targeted university administrations for not doing enough to counter racist incidents and elements on campus.

One case was at Yale University, where students demanded the removal of the leaders of one residential college (Silliman) and the renaming of another one (Calhoun College). They also demanded changes to Yale's curriculum, greater mental health support, millions of dollars in additional funding for cultural centers and services for international and low-income students, and better training and reporting regarding racial bias in classrooms and by Yale affiliates. The other case was at the University of Missouri's flagship Columbia campus, where students' demands included removal of the UM system president, curricular changes, and racial awareness training. They also demanded increases in the percentage of black faculty and staff, more resources and staff for mental health support, and a strategic 10-year plan to increase retention for minority students, sustain diversity curriculum and training, and promote a safer and more inclusive campus (We the People, 2019).

In both cases, the protestors achieved their key goals: at Yale the leaders of Silliman College stepped down and Yale's administration changed the name of Calhoun College to Grace Hopper College, while at UM the president and campus chancellor resigned while the UM Board of Curators adopted new policies and voted for additional resources to address diversity and discrimination issues at the university.

Yet the broader outcomes were quite different, and not at all what was expected. At Yale, though initially the conflict was highly contentious and drew a host of bad publicity, negotiations nonetheless produced a widely-accepted process for examining and altering names of buildings and facilities across the university that not only resolved the immediate issue but also left a framework for the peaceful resolution of similar grievances. The resolution was achieved in a way that satisfied students in the movement yet did not alienate other students, alumni, potential donors or other stake-holders in Yale's social field. In contrast, at the University of Missouri the conflict was resolved in a way that satisfied students in the movement, yet antagonized other actors. The conflict produced issues regarding the university that percolated into the state legislature, resulting in financial sanctions. The conflict also produced negative publicity that hurt applications, especially among prospective Black students. The result was that even though the movement clearly achieved its explicit goals, the University of Missouri ended up enrolling fewer Black students, and had fewer overall resources for educating its students, after the success of the movement than before-surely not the outcome that the protestors desired.

In these paired studies, we show how the tactics of the protestors and the responses of their targets, and the interactions of these challenger-target dynamics with the wider social movement field, produced these outcomes. In both cases, an essential part of the story is whether or not, in pursuing the conflict between the 
social movement and its target, actors on both sides showed concern for the views of the wider public or other important actors, and for how their conduct and resolution of the conflict would impact other important groups. At Yale, both protestors and the targeted administration sought an inclusive solution that achieved consensus regarding desired changes with that wider public. At Missouri, by contrast, the desired changes were achieved by a confrontation that pressured and undermined elements of the target institution, in large part because the University of Missouri administration was divided and unresponsive, and unable to look beyond its own internal concerns. The interactions of administrators and protestors then provoked negative perceptions and sanctioning actions from several other groups in the wider social movement field.

Tarrow (2010) argues for a "paired comparison" approach to historical data. A small number of cases are selected that are similar in most respects. The cases are then examined in greater detail to see how differences among them may account for divergent outcomes. For example, Tocqueville, in two books, compared the political culture of Fance and the United States to explain divergent outcomes. This corresponds to our approach. We show that using the theory of social movement fields can help us understand the contrasting outcomes of these two apparently similar cases.

The data for the two case studies were collected from several sources. The descriptive accounts are based on a variety of secondary sources, including university issued reports and media accounts. We also use data published by the two universities on enrollment trends and on funding.

\section{Yale University-the center holds}

At Yale University, in late 2014 and 2015 a series of campus-wide protests broke out to protest racial insensitivity. The protests were spurred by the Black Lives Matter movement, the controversy over the Trayvon Martin shooting, and first focused on national racial issues. In November, 2014 Yale students across campus walked out of classes to protest the non-indictment of the police officer who shot Michael Brown in Ferguson (Potash, 2014). They blocked traffic while chanting "Black lives matter." They raised their hands for four and a half minutes to memorialize the four and a half hours that Brown's body laid on the streets. But the protests soon focused on conditions at Yale, pressing claims that the university had not taken enough steps to support minority students and curb racism.

One of the protest targets with the most-wide ranging import was the renaming of Calhoun College, which memorialized Yale graduate John C. Calhoun, who as a congressman, Senator, and U.S. Vice-President was a leading defender of slavery. Changing the name of Yale buildings, some of which had names dating back centuries, went to the heart of Yale's identity and to the question of whether the administration alone or the students had a voice in factors that shaped their daily experience at Yale. Living and working in a building named for a champion of slavery seemed like a daily humiliation for students protesting a racially insensitive climate at the university. 
Two incidents intensified the controversy over racial tolerance on campus, setting the condition for the Calhoun controversy to take center stage. In November 2015, a Yale fraternity turned away black women from a party, allegedly saying it was for "white girls only" (Svrluga, 2015; Brown, 2015). While the fraternity denied that this happened, the accusation was widely discussed on campus. Second, days later, the university's Intercultural Affairs Office (a group of administrators including those from the cultural centers and Chaplain's office) sent an email to all undergraduates (Ye, 2015). The email cautioned students not to wear Halloween costumes that might offend cultural groups, such as would wearing blackface, turbans, and feathered headdresses (Email from The Intercultural Affairs Committee /https://www. thefire.org/email-from-intercultural-affairs/). Erika Christakis, a Yale lecturer and the associate head of Silliman College (one of Yale's 12 residential colleges), wrote a response to the email. She acknowledges that costumes should be selected with cultural sensitivity, but also supported the right of students to wear potentially offensive costumes as protected by the principle of free speech. She further commented that the capacity to put up with affronts is a hallmark of an open society. The head of Silliman College, Nicholas Christakis (a Yale professor and her husband), publicly backed her. In a video that went viral, protestors confronted Nicholas Christakis in a college courtyard. Several students yelled at Christakis that he should be removed from his position at Silliman (Wang \& Wang, 2015).

The two controversies were followed by a demonstration by 300 students (Stanley-Becker, 2015a). They made demands for the hiring of additional black faculty, racial sensitivity training for first year students, and the dismissal of any university administrators who were inattentive to racial issues on campus. When the dean of Yale College, Jonathan Holloway, appeared, protestors surrounded him, demanding change. A week later, another demonstration, this one involving 200 students, marched to the university president's home. They presented a set of demands, which they said superseded the demands of a week earlier (Shimer \& Wang, 2015). The new demands included increased funding for cultural centers, university creation of an ethnic studies program, and the resignation of the head and associate head of Silliman College.

Faculty pushed back on one of the demands. Within two weeks, 49 faculty signed an open letter defending the email of Erika Christakis. Those signing included the heads of two other Yale colleges and numerous senior faculty. The open letter said that Erika Christakis's email was a reasonable effort to foster discussion about a racially sensitive issue, and supported her view that social guidance on costumes should come from the students themselves, from the bottom up rather than the top down (Yaffe-Bellany, 2015). University President Peter Salovey and College Dean Jonathan Holloway rejected the demand to remove the Christakises from their positions at Silliman College or otherwise sanction them. Although Salovey and Holloway continued to support them, to end the ongoing confrontations the Christakises voluntarily resigned from their positions at Silliman College in May 2016 (Shimer \& Yang, 2016).

The demand to change the name of Calhoun College raised significant additional problems. Not only current students, but also generations of alumni had an interest in the College, and any change would set precedents on the naming of 
other buildings. President Salovey initially rejected the demands to rename the College. He argued that to change the name would conceal rather than highlight the harms of slavery (Banchiri, 2016). Others in the Yale community joined in expressing their opposition toward renaming. A member of the class of 1971, also a Yale faculty member, told a local reporter, "As a Calhoun person, it's very personal for me... I'm a Hounie; I've been a Hounie for a lot of years already... The name and the flag, it all means something to me" (New Haven Register, 2015). Others raised concerns about a slippery slope in regard to renaming. If the university conceded to rename Calhoun College, might not the university slide into renaming many other buildings, or even Yale itself? Yale's namesake, Elihu Yale, had been an active trader of slaves (Yannielli, 2014; Committee to Establish Principles on Renaming, 2016, p. 7). Where would the renaming end? There was also concern that a name change would alienate alumni donors who, across several generations, had rallied behind the Calhoun College name (O'Reilly, 2016). On April 27, 2016, President Salovey announced that the Yale Corporation had decided the Calhoun name would not change.

Shortly after the non-renaming decision was announced, a group of 600 students, dressed in black, assembled in front of Calhoun College. They expressed disappointment in the decision, and claimed that there was an absence of respect for student opinion and concerns on the part of the administration. But they had not given up hope of forcing a change in the College's name (Yale Daily News, 2016).

In fact, mobilization to remove the Calhoun name gained momentum. Four hundred faculty (about one-half the faculty of College of Arts and Sciences) signed an open letter objecting to President Salovey's decision to retain the Calhoun name (Shimer \& Wang, 2016a). Students across the university debated the renaming, nowhere more intensely than within the College itself. Professor Julia Adams (2016), then the head of the Calhoun College, told us the tenor of conversations within the College was extremely intense, but involved an active search for something new and an uncertainty about its ultimate direction (personal communication, April 22, 2019). The College decided to hold a series of forums to discuss the issues, including those with a distinguished historian of the antebellum period and with representatives of the Yale Corporation (Yale's board of trustees). In Adams's assessment, the student conversations within the college were "a model of informed discussion." There was confrontation over a profoundly-felt injustice, but also a "genuine civility" in communicating with diverse parties, and deliberate efforts to seek a solution that would not leave important groups engaged with Yale with a feeling of grievance.

An exceptional act of militancy occurred when an African-American worker in the Calhoun cafeteria shattered a stained-glass panel that depicted slaves transporting cotton. He explained that "no employee should be subject to coming to work and seeing slave portraits on a daily basis" (Greenberg, 2016). Although the employee was arrested by Yale Police, the university reacted with moderation, and declined to press charges. Meanwhile, students rallied on the employee's behalf, and gathered additional support. A letter calling for his reinstatement was signed by 850 students, alumni, and others (Liu \& Xu, 2016). Although the employee resigned from Yale, he was later rehired (Branch, 2016). In what was a highly unusual case of employee, 
administration, and students coming to agreement, what could have been a potentially explosive event thus was defused.

The fact that students interacted with both members of the Yale Board and Yale faculty and were met with respect and a desire to search for solutions was crucial to how events unfolded. One can consider that if the students had been stonewalled and their concerns dismissed, they might have escalated their protests. For example, other possible tactics might have included sitting-in in the office of the College administrators, or a hunger strike, or other more confrontational measures to force a change in the name of the College. For the University administration, making martyrs by expelling or suspending students for attacking a symbol of slavery, or harshly prosecuting vandalism clearly aimed at an expression of slavery on campus, could have polarized the entire Yale community and its alumni.

Looking for a creative and inclusive solution, the administration decided not to treat this as a case about Calhoun and Calhoun College, but as an opportunity to develop a new set of naming rules for all Yale buildings. In response to continuing protests, President Salovey established a two-stage review to consider the renaming of Calhoun College. In the first stage, the university appointed a committee to develop a set of criteria for the process of renaming any Yale building. Led by a historian, the 12-person University committee developed four principles for assessing possible renamings. They were whether (1) the principle legacy of the namesake is at odds with the mission of the university; (2) the namesake's legacy was debated during his or her life, allowing for a distinction between those who merely went along with the norms of their day from those who actively promoted a loathsome practice; (3) the reason the university had honored the namesake was at odds with the mission of the university; (4) the building or structure plays a significant role in shaping the university community, as a college does but (say) a fountain does not (Committee to Establish Principles and Renaming, 2016, p. 19-22).

In the next stage, also faculty-led, a three-member Committee applied the four principles to the Calhoun renaming (Committee to Establish Principles on Renaming, 2016). Even with a "strong presumption against renaming," the committee recommended unanimously to change the Calhoun name.

The two reports (first, establishing four principles for renaming and, then, their application to Calhoun) gave the university's senior leadership grounds to present their action as a reasonable and respectful acknowledgement of the values of the entire Yale community, rather than as caving in to the demands of protestors. In an open letter to the university, the president stated, "It became clear that Calhoun College presents an exceptionally strong case-perhaps uniquely strong-that allows it to overcome the powerful presumption against renaming" (Salovey, 2017).

At the same time, these actions fully acknowledged the basic principle behind the student protest's demands. Professor Julia Adams observed (personal communication, April 22, 2019) that, even before the new naming principles were articulated, what students and faculty were reacting to was Calhoun's historical role as not just a slaveholder or even an advocate of slavery in its historical context but, more importantly, as the intellectual architect of secession. Calhoun had argued that the states' legal establishment of slavery must always have higher legal standing than the U.S. Constitution. He was "special," but people, while sensing that, were having trouble 
articulating why that was so. The Principles report clarified that specialness, allowing for a full-throated advocacy for the college's change of name. On February 11, 2017 Yale announced that it would rename the college for Grace Murray Hopper, a Yale graduate, path-breaking computer scientist, and a US Navy admiral (Yale Daily News, 2017).

In sum, unlike events at Missouri (which we describe below), the changes at Yale were not a disaster for the university but a solid resolution and an affirmation of university values and the interests of the many parties involved. The outcome was not a simple renaming (i.e., concession by the administration), but the development of new and broad principles for naming Yale buildings and administrative units that would be acceptable to the multiple Yale publics - arguably a wider success than was sought by the original protest. Only then was there a change in the name of Calhoun College, after finding that Calhoun's naming did not meet the new guidelines. ${ }^{3}$

In sum, what had begun as a severe controversy over race on campus-the clashes over a fraternity party admitting minority women and guidance for students not to wear culturally insensitive costumes-escalated with the renaming controversy, the smashing of the cafeteria window, confrontations with faculty and administrators, and the administration's initial decision not to accede to student demands. Yet instead of growing more polarized, both students and administration sought an inclusive solution that would engage and find acceptance with other Yale stakeholders. Student protestors' demands and the Yale administration's response thus evolved into a realignment of all these actors around a new set of naming principles, such that all these actors in the wider social movement field formed a new equilibrium in which acceptance of the name change was firmly embedded. The administration and Yale as an institution emerged strengthened, while the students were satisfied with the administration's actions. What began as an embarrassing campus conflict that drew negative national attention (Freidersdorf, 2015) was favorably resolved for the student movement in a way that allowed multiple actors to accept and endorse the actions adopted to resolve the conflict.

But it could have gone otherwise. In fact, on November 9, an article Inside Higher Ed focused on both Yale and the University of Missouri as the leading sites of escalating racial tensions at U.S. universities (Jashcik, 2015). We shall see below how things unfolded in the latter.

The student movement's longer-term success can be seen by the number and percentage of African Americans enrolling in Yale's Freshman class in the following years. Both of these indicators rose significantly in the four years following the race protests of 2014-2015 (see Table 1). By contrast, we will see that these key indicators declined at Missouri in the wake of their disruptive events.

\footnotetext{
3 The consensus over renaming Calhoun was not without exceptions. Anthony Kronman (2019a; 2019b), a former dean of the Yale Law School, published a book, followed by an article in the Yale Daily student newspaper, criticizing the renaming decision. His central point is that American universities are becoming overly politicized, giving in to unreasoned popular demands. In particular, the decision to rename Calhoun serves to conceal Yale's history of entanglement with slavery, rather than confront it. Kronman, however, was not an active participant in the controversy.
} 
Table 1 Yale university, degreeseeking students, first-time, first year

\begin{tabular}{llll}
\hline & $\begin{array}{l}\text { Black or African } \\
\text { American, non- } \\
\text { Hispanic }\end{array}$ & Total & $\begin{array}{l}\text { Percent black or } \\
\text { African American } \\
(\%)\end{array}$ \\
\hline $2013-2014$ & 94 & 1358 & 6.9 \\
$2014-2015$ & 87 & 1360 & 5.1 \\
$2015-2016$ & 96 & 1363 & 7.0 \\
$2016-2017$ & 99 & 1367 & 7.2 \\
$2017-2018$ & 122 & 1579 & 7.7 \\
$2018-2019$ & 129 & 1573 & 8.2 \\
\hline
\end{tabular}

Office of Institutional Research, Yale University, Common Data Set, https://oir.yale.edu/common-data-set

\section{The University of Missouri at Columbia: The center does not hold}

Our second case study is a protest movement at the University of Missouri's flagship campus in Columbia, also during the period 2014-2016. Like Yale's racial controversy, this protest arose in the context of the Black Lives Matter movement (BLM). In August 2014, police shot dead an unarmed eighteen-year-old, Michael Brown, in Ferguson, Missouri. Demonstrations erupted in many locations (Milkman, 2017, p. 32), including on the Columbia campus of the University of Missouri, 110 miles from Ferguson. Students marched in protest, leading university officials to set up several forums on race relations (Belkin \& Korn, 2015).

As at Yale, in the following year a protest movement emerged in full force on the Columbia campus that focused on local racial issues. In September 2015, in an event called "Racism Lives Here," protestors expressed grievances about the racial bigotry expressed on campus and anti-gay sentiment (Naskidashvili, 2015). A month later, students formed a protest organization, Concerned Students 1950, so named after the first year that the university admitted African American students.

In early November 2015, an African American graduate student Jonathan Butler began a hunger strike to protest the University administration's handling of several race-related incidents, vowing to forgo all food and nutrition, even up to the point of death, unless the president of the university resigned or was fired (Addo, 2015a; Maese \& Babb, 2015). Butler stated that the university's president "had ample opportunity to create policies and reform that could shift the culture of Mizzou in a positive direction but...[he] failed to so" (Kovacs, 2015).

Soon after Butler began his hunger strike, the football team, led by its African American players, pledged that they would boycott all practices and play in no games until the president of the university resigned or was removed from office (Addo, 2015b). The football coach backed the refusal, stating "The Mizzou family stands as one. We are united. We are behind our players" (Mendoza, 2015; Heffran 2016 , p. 75). Under a contract with its football opponent, the university would forfeit $\$ 1$ million if it did not play its next game. In a photograph released by the protestors, Butler was standing, in solidarity, next to the boycotting football players (Maese \& Babb, 2015). 
The same week, while hundreds of prospective students were on campus for a recruitment day, protestors held a mock tour. They recalled racist incidents on campus including the use of racial slurs against two African American women near the Student Recreation Complex (Sawey \& Schrader, 2015). Adding to the protest's momentum, the Faculty Council, the main faculty governance body of the campus, issued a statement stating that it was concerned about "the lack of communication and uncertainty about the leadership" of the university system and the Columbia campus (Belkin \& Korn, 2015). The following week, in the middle of November, unable to resolve the growing chasm between the students and the administration, both the university president and the Columbia campus chancellor announced their resignations. Shortly after the resignations, the Board of Curators, the university's governing body, issued a set of initiatives to address racial tensions on campus, including hiring a diversity officer for the entire university system. The university also pledged to provide support to all students, staff and faculty who experienced discrimination, to develop a task force to improve diversity and inclusion, and to mandate diversity and inclusion training for all faculty, staff and incoming students. The White House press secretary lauded the protest as showing "that a few people speaking up and speaking out can have a profound impact" (McManus, 2015).

The Black Lives Matter-inspired protest movement at the University of Missouri had thus achieved a notable victory by the usual criteria for protest success. It achieved its central demands versus its target: the toppling of the university president, and the commitment of new resources to address the protestors' grievances and improve the atmosphere for diversity and respect for all groups on campus.

Yet, in spite of these gains, or arguably because of them, the university experienced a subsequent reversal of fortune. The sudden resignations of the university president and campus chancellor-which were seen in the state capitol as capitulation to the students-led to a backlash against the university in the state legislature, and to dissatisfaction among alumni and outside funders that substantially damaged university finances. Of even greater concern, negative publicity about the confrontations and racial tensions on campus produced a sharp downturn in applications to the Columbia campus. The departing university president, Tim Wolfe, claimed that the financial losses due to declines in state funding and enrollments because of the conflicts would amount to $\$ 25$ million (cited in Trachtenberg, 2018, p. 79). The forced resignations of the university president and campus chancellor, reported the New York Times, "was a moment of triumph for the protesting students. But it has been a disaster for the University" (Hartocollis, 2017).

The evidence for this "disaster" includes a one-third decline in new college degree-seeking students over a two-year period. ${ }^{4}$ Moreover, despite the new commitment to diversity, the decline was largest for African Americans, which fell by $41 \%$ percent (see Table 2 ). This was in sharp contrast to Yale in the same periodthe two years after its race protests of 2015-2016 - in which (as shown in Table 1)

\footnotetext{
${ }^{4}$ Data from "Table E-3-E. Degree Seeking First-Time College Enrollment by Gender and Ethnicity." Institutional Research and Quality Improvement (01/18/2017) University of Missouri. http://ir.missouri. edu/enrollment/e3-e.pdf
} 
Table 2 University of missouri, columbia, degree-seeking students, first-time, first year

\begin{tabular}{llll}
\hline & $\begin{array}{l}\text { Black or African } \\
\text { American, non- } \\
\text { Hispanic }\end{array}$ & Total & $\begin{array}{l}\text { Percent Black or } \\
\text { African American } \\
(\%)\end{array}$ \\
\hline $2015-2016$ & 509 & 6191 & 8.2 \\
$2016-2017$ & 294 & 4772 & 6.2 \\
$2017-2018$ & 309 & 4134 & 7.5 \\
$2018-2019$ & 397 & 4673 & 8.4 \\
$2018-2019$ & 397 & 4673 & 8.4 \\
$2019-2020$ & 346 & 5431 & 6.4 \\
\hline
\end{tabular}

University of Missouri, Columbia, Degree-seeking Students, Firsttime, First year Institutional Research \& Quality Improvement, University of Missouri, Common Data Set, https://irqi.missouri.edu/mudata/common-data-set/

Yale gained a $27 \%$ increase in the number of African-Americans in its Freshman class.

The negative reaction of the state legislature to the protests led the state to reduce its contribution to the university: "Before the protests, the university... was experiencing steady growth and building new dormitories. ... [After the protest events], "with budget cuts due to lost tuition and a decline in state funding, the university is temporarily closing seven dormitories and cutting more than 400 positions, including those of some nontenured faculty members, through layoffs and by leaving open jobs unfilled. Few areas have been spared: the Library is even begging for books" (Hartocollis, 2017)..$^{5}$

It did not have to be this way. The student protests were uniformly peaceful. If the administration had reacted with alacrity and respect in response to the students' concerns, the positive measures taken by the Curators would likely have been welcomed and the campus leaders need not have resigned. But that is not how the dynamic of protest-target interactions unfolded.

Throughout September and October 2015, African-American students staged multiple meetings and protests to call attention to racial slurs being hurled at them on campus. But an increasing focus of the protests was the lack of attention given to the students' grievances by the administration, and the latter's inaction in responding to student requests (Trachtenberg, 2018, p. 75). On October 10, a group of students blocked the president's car in the MU Homecoming parade, in an effort to call his attention to racial grievances on campus. The president did

\footnotetext{
5 The University's annual fiscal report observes “[b]udget cuts have dominated discussions of spending at MU since the beginning of 2016, when the enrollment crash following the November 2015 campus protests became apparent and then-interim Chancellor Hank Foley ordered 8 percent budget cuts" (Keller 2018). University of Missouri System (2018), p. 27.

Interestingly, to show the complexities of the social movement field, Missouri's alumni responded to the disorder and threats to their university by raising their donations. But these efforts were far from sufficient to offset the financial losses resulting from a hostile state legislature and a major drop in applications and enrollments. This further illustrates the need to assess the impact of protest and target concessions on all important actors in the wider movement field.
} 
not get out of his car or engage the students; he simply waited for the police to clear the students from the parade route. President Wolfe then ignored the outrage this event caused for two weeks; only on October 26 did he finally host a group of black students in his office for discussion. Trachtenberg (2018, p. 95), a faculty member of the University's School of Law, observes "[b]y all available accounts, the meeting was a disaster. One student attendee told me afterward that he entered the meeting prepared to find common ground with Wolfe but was treated with such transparent disrespect that he left determined to see Wolfe fired. Jonathan Butler described it as follows: "Being in a meeting with Tim Wolfe... he doesn't acknowledge our humanity, he doesn't acknowledge that we exist, we're nothing to him." Butler began his hunger strike on November 2, one week after the meeting.

The administration responded slowly and awkwardly to events in part because of internal feuding. Wolfe had recently hired a new campus chancellor, Bowen Loftin. Loftin in turn had eased the deputy chancellor into retirement and not replaced him. That deputy chancellor, Michael Middleton, was an African American who had previously served in a variety of administrative roles and had played a key role in handling racial issues on the Columbia campus. His departure left the new administrators, Wolfe and Loftin, without any experienced communications channel to the university's Black students. Meanwhile, Loftin had made himself unpopular with the faculty. As the protests escalated, and the president himself became a target, Wolfe became convinced that Loftin had somehow shifted blame to him for the turmoil on the Columbus campus. Thus, at the early stages of the protests, before the hunger strike and football players' threatened boycott, when "Wolfe and Loftin should have been coordinating their response to student protests and crafting a strategy to promote diversity and inclusion at the university, the president was considering whether to fire the chancellor. And the chancellor knew it." (Trachtenberg, 2018, p. 96).

One could add that Wolfe himself was new to academe. Having been recruited by the Curators as a successful industry executive, he had no experience with campus management or student protests. He clearly did not appreciate the need to move quickly to defuse the crisis, nor did he recognize how an escalation of student protests would resonate with the state legislators, who long had harbored animosities toward the university.

Students and faculty also deserve some blame for polarizing the crisis. Black students were understandably enraged at President Wolfe, who acted pre-occupied, ignored their protests for weeks, and then treated them badly when they finally had a meeting. They then focused their efforts on getting Wolfe fired. Their tactics - the hunger strike and the football boycott - were both dramatic and effective. However, these actions also had the result of focusing national media and alumni attention on the conflict, drawing in the Curators to demand Wolfe's resignation, as well as the ire of state legislators and alumni. Black students also staged mock tours and other events on campus to more widely publicize the negative racial atmosphere. While these may have hastened Wolfe's departure and encouraged the legislature to add resources for diversity training and other worthy things, they also created a widespread but misleading impression that Missouri's Columbia campus was especially hostile to Black students and was experiencing exceptional racial conflicts. 
While students were clearly focused on getting rid of Wolfe, feeling that no progress could be made with him in office, they had no direct contact with the Curators, relying instead on pressure tactics to force their hand. Seeking mediation from the Curators or alumni to ease Wolfe out of office would have had fewer negative repercussions than a threated boycott of the widely-valued football team. Unlike at Yale, where members of the Yale Trustees and faculty met with students from the outset, President Wolfe did not meet with faculty nor students on these issues, and the Board of Curators remained distant and maintained their confidence in President Wolfe until right before they demanded his resignation.

Even the day that Wolfe's resignation was finally announced did not go well. African American students who had been camped out on campus, and been waiting up all night for news, asked that the media-who in recent days had descended on campus-be kept away from their protest site so that they could celebrate, rest, and clean up in peace. They were supported in this by faculty, but one faculty memberan assistant professor of communications, Melissa Click-was captured on video being overly aggressive and harshly condescending to two photographers (one a student at the university) who were trying to take pictures of events after Wolfe's resignation. Click told the student photographer that she had to "get out," and dismissed the photographer's statement that the campus was public property. Click was filmed asking for "some muscle" to remove them.

The video went viral and created a firestorm. Click was attacked on some sides for being an enemy of the First Amendment, attacked from others for threatening a student, and attacked by others for defending the protestors. She was subjected to vicious emails that contained racist epithets and threats of rape and death (Trachtenberg, 2018, p. 104). Yet no formal complaints were filed, Click apologized to the photographers, and the matter went no further.

That is, until a state senator made a political case out of it, and almost two months later over a hundred state legislators signed a letter calling for Click's immediate dismissal. This put the university's new administrators in a precarious position. On the one hand, they were loath to fire a faculty member who had committed no violent or illegal act at the request of politicians, as this would be a breach of the long-standing independence from political interference in personnel decisions that Universities have long claimed. Even faculty who found fault with Click's actions did not want the university to give in to pressure from the state legislature. So, the university dithered; and "as the 2016 elections approached, attacking the university was quite popular with many Missouri voters, and office-seekers obliged." (Trachtenberg, 2018, p. 106).

The Click matter dragged on until mid-February, when a majority of the Board of Curators, under outside pressure, voted to fire her, over the objections of both the university Administration and the Chair of the Board. The result was to make the university administration, now under new leadership, look weak and ineffective, even months after the campus protests had ended.

Again, the university's leadership had given little thought to how the viral video would play with diverse actors outside the campus. If they had acted quickly to suspend or otherwise discipline Professor Click for her conduct, they likely could have avoided the letter from the state legislators that came six weeks later, and the 
Table 3 Missouri state appropriations to university of missouri, system-wide

\begin{tabular}{ll}
\hline Fiscal year & $\begin{array}{l}\text { Appropriations in } \\
\text { thousands of dollars }\end{array}$ \\
\hline 2010 & 496,358 \\
2011 & 437,631 \\
2012 & 397,692 \\
2013 & 406,400 \\
2014 & 412,650 \\
2015 & 435,511 \\
2016 & 438,813 \\
2017 & 417,912 \\
2018 & 401,705 \\
2019 & 408,797 \\
\hline
\end{tabular}

Financial and Compliance Reports, University of Missouri System. https://www.umsystem.edu/ums/fa/controller/financial-reports

subsequent spectacle of an assistant professor being fired by the Board of Curators for essentially politically controversial actions.

Given how the protests were handled by the university administration, whose actions encouraged escalation and confrontation and showed no sensitivity to the wider context, it is hardly surprising that the results were disastrous for the university and even for the Black student movement, who saw their university's reputation damaged, its resources cut back, and applications from Black students plummet. Though they achieved their goals of having the president dismissed and obtaining resources for diversity concerns, these wider effects were hardly what they had sought.

The students' success and the administration's capitulation did not win support with the state legislature, the population of the state, or even potential AfricanAmerican student recruits. Instead, all these other groups viewed the protest campaign and its results as evidence of undesired discord on campus, negatively framing the institution in the eyes of necessary supporters. Rather than engaging all the relevant actors in the social movement field to produce a widely supported outcome, as occurred at Yale, the movement focused only on its specific target, the university leadership. Achieving its goals produced a victory, but a victory that weakened rather than strengthened the institution. The unexpected and surely undesired result of the protests' dramatic victory over the administration was a university campus that, two years later, had fewer first-time college African American students, and fewer overall resources, then before the protests began. The consequences of the protest were experienced University wide, not just at the Columbia campus, according to the University's annual fiscal report: "the two past fiscal years represented unprecedented challenges during which students protested over the racial climate on the Columbia campus. The events resulted in a decline in enrollment by $4 \%$ in FY 2017 and FY 2016 across the University; comprised mostly of first-time entering freshman, which will create challenges over multiple years." (University of Missouri System (2016, p. 28). 
Table 3 shows the trend in state appropriations for the University. From 2012 to 2016, appropriations steadily recovered after the 2009-2010 great recession, growing by $11 \%$ in five years; but after 2016 appropriations sharply declined, falling almost $20 \%$ by 2018 .

\section{Redefining social movement outcomes}

To be sure, there are many factors that account for the different outcomes in these two cases. Yale is a rich private school in a generally progressive northeastern state, with exceptional resources to respond to requests for additional spending. The University of Missouri is a public university in a state with a long history of racial segregation (Mizzou admitted its first Black undergraduate only in 1950, eighty years after Yale had done so). The University of Missouri is also far more dependent on tuition revenues than Yale, and unlike Yale is subject to a state legislature that had long had issues with the University, and whose legislators could attack the University for their own political benefit. ${ }^{6}$

Yet citing these factors simply makes clear the importance of our claim that movement outcomes must be analyzed through examination of how movement-target interactions affect the wider social movement field. At both Yale and the University of Missouri, protestors carried out peaceful but disruptive protests, sustained over several months. At both universities, administrators, after first resisting, granted many of the protestors' key demands, including the resignations of figures that the protestors deemed hostile to racial equity. Thus, both cases could reasonably be considered, in a movement-centered approach, to have achieved similar success.

Our argument is that movement outcomes should be defined not just as winning a favorable policy outcome from the target, but as how the movement and its interaction with targets and other groups has changed the wider social movement field in which the movement has acted. Using this definition, we find that the outcomes were in fact quite different. At Yale, debating and adopting new institutional arrangements for naming Yale buildings forged an inclusive consensus among diverse actors in the movement field on how to address this key concern about the racial climate and legacy at Yale. At Mizzou, the pattern of protestors' action and administration responses escalated and polarized the conflict. This produced sharply negative perceptions of the racial climate at the university among potential applicants, while the

\footnotetext{
${ }^{6}$ It is sometimes asserted that Yale is uniquely decentralized in its structure, with students and faculty having a great deal of autonomy to negotiate solutions to conflictual situations. This is overstated, even mistaken. As of June 2021, Yale continues to be organized into fourteen schools: the undergraduate Yale College; the Graduate School of Arts and Sciences, and twelve professional schools. Each school's faculty oversees the relevant curriculum and degree programs. Within the undergraduate College, there are also fourteen residential colleges. All undergraduate students are affiliated with a residential college. https://yalecollege.yale.edu/residential-colleges. Many faculty from across the university are residential college fellows, while others choose not to affiliate. Julia Adams (head of Grace Hopper College), stated "undergraduate academic life is not markedly decentralized as compared to other US universities" (Personal communication, June 28, 2021).
} 
impact of the conflict on the state legislature created a far more hostile and damaging situation for the university. Thus, the victory of the student movement shifted the university's relations with other key actors in the wider movement field. These shifts undermined the goals for which the protestors had fought, despite their achievement of their immediate policy objectives.

Social movement scholars might argue that such "paradox of victory" effects are relatively rare, and are already implicitly considered in many analyses of social movement outcomes. Yet as we show below, such effects are not at all rare. Rather, as the political sphere in the U.S. and other countries has become more polarized, creating deeper and more hostile fissures in the wider social movement fields in which social movements must operate, such effects are becoming ever more common.

Moreover, whereas other areas of sociology have explicitly addressed how such paradoxes of victory are a regular part of outcome dynamics, the theory of social movement outcomes is unusual in not making it an explicit part of its treatment of movement outcomes.

\section{Analytic parallels}

In the theory of social movement outcomes, changing incumbents or policies is generally considered a criterion of movement success. The dynamics by which such victories paradoxically can lead to later setbacks are not generally seen as inherent in the actions of social movements. Yet in this, the study of social movements is an outlier. In related fields of social science, the appreciation of how contestation dynamics can influence wider fields of action, and victories lead to larger failures, is well established. This is clear in two fields that are often intertwined with the study of social movements: the sociology of revolutions and the sociology of law.

Similarities between social movements and revolutions have often been noted (Goldstone, 1998; Moss \& Snow, 2016, Goldstone \& Ritter, 2018). Yet the characterization of revolutionary outcomes is very different from that of social movements. In the sociology of revolutions, it is a commonplace that revolutions can be both successful in triumphing over their target, and yet failures in achieving their broader goals. Successful revolutions, almost by definition, are those that have won contests against incumbents and produced major changes in the policy environment. Yet such events are still often argued to have failed because they promised to bring democracy, equality, and prosperity but in fact failed to achieve these outcomes under the new revolutionary regime (Arendt, 1963). Whether one considers the French, Russian, Chinese, Cuban, Iranian or other revolutions, the outcomes of authoritarian regimes and decades of economic stagnation are considered - at least by Western critics - to evidence a lack of success relative to their announced goals, even if the revolutionary movements were able to overthrow their targets, the incumbent states.

Some scholars consider such failures to be a result of these promises being utopian to begin with; some consider that these idealistic goals were never more than propaganda to veil the more basic goal of gaining power. But more recent scholars argue that these failures were a result of how the process of revolution 
unfolds. Where violent tactics lead to counter-revolution and civil war, revolutionary leaders turn to extreme measures and authoritarian government (Skocpol, 1979; Goldstone, 2014, Stone, 2015). By contrast, non-violent revolutions are far more likely to succeed in establishing stable democratic governance (Nepstad, 2011; Chenoweth \& Stepan, 2011). In other words, it is how the victory over the target authorities is achieved, and how the conflict transforms relationships among other actors in the wider political field, that determines longer-term success.

In this essay, we have argued that social movements, like revolutions, can and often do produce unwanted outcomes even when they succeed in their goals of achieving desired changes in their targets. As with revolutions, we believe that whether or not such unwanted outcomes arise depends on the interactions between the social movement and its supporters and other actors in the broader social movement field. In particular, inclusive and consensus-building approaches are more likely to realign the social movement field in a way that defuses opposition and helps embed favorable outcomes in a new equilibrium alignment among actors in the wider social movement field. By contrast, victories achieved through extreme confrontation tend to create hostile responses in the wider field, polarizing that field between supporters of the movement and its goals, and enemies of them. If the enemies hold or gain positions of power, the result may not be just the undoing of the movement's victory, but may instead be a situation in which other things the movement values are overturned, the atmosphere for the movements' supporters becomes hostile, and the overall position for the movement and its supporters is arguably worse than before.

The sociology of law also recognizes the paradox of victory. Legal scholars routinely differentiate between the outcomes of particular cases, which are contests in which benefits or costs accrue to a particular winner and loser, and changes in the interpretation of case and statute law that alter the wider legal field, which then shapes future legal contests and decisions. Only certain cases shape the law in major ways. Moreover, cases that are settled, rather than contested to a final decision, generally do not shape the wider legal field at all. In an essay subtitled "The Paradox of Losing by Winning," Catherine Albiston (1999) makes the point that only a tiny fraction of judicial decisions - usually appellate decisions - result in changes in the wider legal field. Other cases that are settled or even decided by jury verdicts do not. “... a jury verdict does not change the judicial interpretation of the law or hold precedential value for the cases that follow. Without a published judicial opinion, the results of trials are invisible to the developing body of precedent." She argues that power holders will often agree to settle and concede victories to plaintiffs to avoid appeals that might shift the broader legal field.

Indeed, even with victories in changing statute law, success may be elusive unless the legal community of judges and law enforcement shifts its alignment with respect to how they interpret and implement the new law.

For example, the civil rights movement of the late 1960 s is widely seen as having achieved multiple successes, both in terms of greater inclusion of Blacks in the political process as voters and elected officials, and in achieving major changes to the U.S. legal code in regard to voting rights, access to housing, and 
protection against employment discrimination (particularly the landmark Civil Rights Act of 1964).

Yet these victories have turned out to be more varied in their outcomes than it first appeared. When legal sociologists Pedriana and Stryker (2017) examined the wider outcomes that followed passage of the Voting Rights Act, the Fair Housing Act and the Civil Rights Act (all passed in 1964-1969) they found that by the twenty-first century, these movements in fact had produced very different outcomes. While Black voting rights had expanded significantly, Black wages and employment status still lag substantially behind that of Whites, and in US cities and suburbs that contain a disproportionate share of the nation's minority population, racial residential segregation remains extreme (Massey, 2016, p. 6).

Pedriana and Stryker demonstrate that these diverse outcomes arose not from differences in the actions of social movement protestors, but from how another critical actor in the wider movement field-the legal professionals who subsequently developed standards for implementation and enforcement of the new laws-interpreted the movements' grievances and remedies. That is, where the legal profession saw a group harm, which they often did with measures to hinder Blacks from voting, the laws were vigorously enforced. Where the legal profession only saw individual harm, as with many cases of employment discrimination and almost all cases of housing discrimination, the laws were far more weakly and unevenly applied.

If we consider the broader social movement field regarding civil rights, it is clear that where the wider public had been brought into sympathy with the goals of the social movement, influencing legal professionals, the successful outcome that the movement achieved, namely new laws and policies, was more likely produce a desired outcome that was stable and lasting. In contrast, where the wider public remained hostile-or in backlash became even more hostile to the movement's goals - the broader outcome in the wider legal field was commonly a dilution of the movement's achievement or even its reversal.

Thus, the principle that all Americans had the right to vote achieved wide support, and received strong legal backing. Substantial popular opposition to Black voting remained strong only in a handful of states in the South. The principle that Black workers deserved equal pay and promotion opportunities had moderate national support, but the initial means of implementation, including affirmative action quotas, had little or none and led to a backlash against diversity quotas in both workplaces and educational institutions. The principle that Whites should not choose to live in predominantly White neighborhoods was never widely supported and was in fact often defeated by White movement to the suburbs and local pricing and zoning practices, despite the change of laws.

Changing the laws may appear to be a clear victory for a social movement that aimed to sway government to change those laws. But such victories do not lead to the broader success sought by the movement unless the wider social field of legal interpretation, implementation, and popular support become realigned to support both the goals of the law and the methods of its implementation. 


\section{Further examples from U.S. politics}

It might be thought that such "paradoxes" of victory are rare and found only in a few circumstances. $^{7}$ Yet we would argue that they arise more commonly than expected. Indeed, in recent years the polarization of politics in the U.S., in place of governing by consensus (Andris et al., 2015), has meant that movements seeking policy changes are particularly prone to the problem of "narrow victories," where movements achieve their goals but fail to realign a broad spectrum of actors and groups to accept this outcome. Thus, the Affordable Care Act, passed by a slim Democratic majority, has been targeted by Republicans who have ended the individual mandate and greatly reduced the Medicaid expansion intended by the law. Conversely, the Trump tax cuts, passed by a slim Republican minority, seem destined to be undermined by a Democratic administration seeking to expand government spending on health and infrastructure. Social movements for greater access to health care and lower taxes both worked for decades to achieve these policy successes, only to see them substantially threatened or undermined within a few years by the lack of consensus and any equilibrium of support for these outcomes.

Of course, not all challenger movements have succumbed to this adverse dynamic. Sometimes hard-won success is embedded in a new alignment of diverse groups. The struggle for gay rights, which was arguably more difficult than the struggle for wider health care coverage, developed differently. The gay rights struggle became dramatically public in the Stonewall riots of 1969 and the emergence of gay pride parades in the 1970s. An even sharper confrontation arose in the 1980s with gay advocates seeking treatment for the HIV-AIDS epidemic as a public health problem, against a prevailing climate of opinion that treated gays as deviants and their health issues as a consequence of their moral failures. The spread of the disease forced many gays into the open, both to seek medical attention and to advocate for fair treatment by public health authorities; in the process the widespread existence of gays as relatives and friends suffering from a dangerous disease humanized what had been, to most, a marginal and underground community. Gays eventually won a role in authorities' deliberations on how to cope with the epidemic and were able to shape the public perception of their rights as citizens (Epstein, 1998). Still, the gay rights movement moved slowly; as late as 1996 the US Congress passed the Defense of Marriage Act (DOMA) by large majorities in both houses, restricting legal marriage to heterosexual unions. Over the next two decades, as gays became more and more visible in public as ordinary citizens seeking the same rights and opportunities as any other Americans, broader public sentiment against gay rights shifted. The process was a long, recursive pattern in which a series of moderate discrete gains were made, but as they slowly unfolded, actors in the wider social movement field shifted positions. PEW research polling found that in 2001 "Americans opposed same-sex marriage by a margin of $57 \%$ to $35 \%$;" but by 2017 that had shifted to $62 \%$

\footnotetext{
${ }^{7}$ We have found only one academic work that treats a social movement outcome explicitly as a "paradox of victory." This is an analysis of the COSATU trade union movement in South Africa. Buhlungu (2010) found that despite COSATU having been an effective part of the abolition of the apartheid regime, the new regime of the African National Congress and processes of liberalization resulted in the "organizational weakening of union structures.".
} 
supporting same-sex marriage and 32\% opposing it (Pew Research Centre 2017). Thus, by the time that the Supreme Court overturned DOMA in 2013, in United States vs. Windsor, the alignment of forces in the wider social movement field had shifted to become generally favorable to gay rights, with only strongly conservative religious groups still opposed. We thus expect that, unlike the Affordable Care Act, the success of the campaign for gay rights will not provoke a subsequent reaction that will overturn its wider goals. ${ }^{8}$

As a final consideration, regarding a point first raised by Piven and Cloward (1977) about movement disruption being necessary to put pressure on elites, our perspective suggests this is the wrong focus. Pressure (either involving violence or non-violent approaches such as marches, hunger strikes, boycotts, and sit-ins) may force changes in the personnel or policies of targets, but it will only produce success if such pressure wins sympathy and support in ways that realign the wider social movement field in a favorable direction. Pressure that wins victories, but while doing so creates enmity among other groups, will likely not produce true success and can lead to even worse outcomes.

\section{Conclusions}

In sum, judging movement success solely in terms of whether a social protest movement achieves desired changes in the personnel, policy, and composition of its target is inadequate. Instead, it is essential to consider the wider social movement field and the reactions and subsequent actions of other groups and publics in that field. Just as it has long been evident and accepted for revolutions, and cases in law, that victories over one's immediate adversary may not advance, and can even reverse, progress toward one's goals, so too social movements that achieve victory over their direct targets may find that this initial success goes on to produce adverse outcomes.

The major determinant of whether such adverse outcomes arise is whether the social movement, in the course of achieving its goals, wins wider consensus and support from additional key actors and publics in the broad social movement field, who come to accept that its goals, and the means of implementing them, are desirable. In such cases, the new consensus can stabilize the social movement outcome and provide a foundation for further progress. But if the movement, in the course of achieving its goals, alienates other groups in the wider social field and fosters polarization and opposition, or weakens the very institutions that it is trying to change and is counting on to enforce the new order, it is likely that the movement's very success will provoke a backlash or further social conflicts. That trajectory is likely to produce outcomes that damage the social movement's wider goals, and in some cases may leave it worse off than it was before its apparent success.

\footnotetext{
8 Van Dyke and Taylor (2019) describe this as a success in "cultural change" rather than political policy change. We agree that change in shifting the culture-which we would describe as a shift in the alignment of groups in the wider social movement field-was essential before stable favorable policy changes could be achieved.
} 
We therefore would suggest a change in the lexicon for analyzing social movement outcomes, and particularly for the identification of movement success. We think it is worthwhile to differentiate between a social movement "victory," in which the movement has been able to change its relationship with, and/or the behavior of, its target groups or institutions, and more lasting "success," in which the movement contributes to a favorable new alignment among the major actors and groups in the wider social movement field. Embedding a victory in such a realignment is crucial to achieving an outcome that does not lead to reactions that harm or overturn the movement's goals.

To be clear, responsibility for the lack of such realignment does not fall only on the protest movement. Political leaders who ram through a narrowly partisan policy victory by a small margin, and movement targets whose reactions or capitulation provoke a backlash from other authorities or weakens their institutions, are harming the future environment for the social movement as much or more than they are helping.

We thus suggest that the shift to viewing social movement outcomes in the wider context of social movement fields provides novel and valuable insights into the conditions and varieties of social movement outcomes. Differentiating between movement "victories" over specific targets, and "success" in contributing to a realignment of the wider social movement field, does bring greater complexity. Yet explicitly embedding outcomes in the wider social movement field, rather than focusing on challengerincumbent interactions, allows us to better understand how social movements' interactions with multiple actors transform the social movement fields in which they contend.

Acknowledgements We thank Julia Adams, the head of Grace Hopper (formerly Calhoun) College at Yale, Ben Trachtenberg of the University of Missouri Law School, and Robin Stryker of Purdue University for their helpful comments on earlier drafts.

Funding This study received no funding.

\section{Declarations}

Conflict of interest The authors declare that they have no conflict of interest.

Open Access This article is licensed under a Creative Commons Attribution 4.0 International License, which permits use, sharing, adaptation, distribution and reproduction in any medium or format, as long as you give appropriate credit to the original author(s) and the source, provide a link to the Creative Commons licence, and indicate if changes were made. The images or other third party material in this article are included in the article's Creative Commons licence, unless indicated otherwise in a credit line to the material. If material is not included in the article's Creative Commons licence and your intended use is not permitted by statutory regulation or exceeds the permitted use, you will need to obtain permission directly from the copyright holder. To view a copy of this licence, visit http://creativecommons.org/licen ses/by/4.0/.

\section{References}

Adams, J. (2016). Graduation remarks. Grace Hopper College, Yale College. http://gracehopper.yalec ollege.yale.edu/graduation-2016-remarks

Addo, K. (2015b). Mizzou football players say they won't play until president is ousted over race issues. St. Louis Dispatch. 
Addo, K. (2015a) Activism going strong at Mizzou, students critical of top leadership. St. Louis PostDispatch, September 6.

Albiston, C. (1999). The rule of law and the litigation process: The paradox of losing by winning. Law and Society Review, 33, 869-910.

Almeida, P. (2019). Social movements: The structure of collective mobilization. University of California Press.

Amenta, E. (2006). When movements matter: The Townsend plan and the rise of social security. Princeton University Press.

Amenta, E. (2014). How to analyze the influence of movements. Contemporary Sociology: A Journal of Reviews, 43, 16-29.

Amenta, E., Caren, N., Chiarelo, E., \& Su, Y. (2010). The political consequences of social movements. Annual Review of Sociology, 36, 287-307.

Amenta, E., \& Young, M. P. (1999). Making an impact: Conceptual and methodological implications of the collective goods criterion. In M. Giugni, D. McAdam, \& C. Tilly (Eds.), How social movements matter (pp. 22-41). University of Minnesota Press.

Andris, C., Lee, D., Hamilton, M. J., Martino, M., Gunning, C. E., \& Selden, J. A. (2015). The rise of partisanship and super-cooperators in the U.S House of Representatives. PLoS ONE, 10(4), e0123507. https://doi.org/10.1371/journal.pone.0123507

Arendt, H. (1963). On revolution. Viking Press.

Armstrong, E. A., \& Bernstein, M. (2008). Culture, power, and institutions: A multi-institutional politics approach to social movements. Sociological Theory, 26(1), 74-99.

Banaszak, L. A., \& Ondercin, H. (2016). Public opinion as movement outcome: The case of the US women's movement. Mobilization: An International Quarterly, 21(3), 361-378.

Banchiri, B. (2016). Why yale will not rename Calhoun College. Christian Science Monitor

Béland, D. (2007). Review of Edwin Amenta, When Movements Matter. Contexts, 6(2), 66-67.

Belkin, D, and Korn, M. (2015). Protest trigger resignations - University of Missouri president, chancellor leave jobs after racial incidents anger students." Wall Street Journal

Benford, R. D., \& Snow, D. A. (2000). Framing processes and social movements: An overview and assessment. Annual Review of Sociology, 26, 611-639.

Branch, M. 2016. Employee rehired after breaking Calhoun window. Yale Alumni

Brown, S. (2015). At Yale, painful rifts emerge over diversity and free speech. Chronicle of Higher Education

Buhlungu, S. (2010). A Paradox of victory: COSATU and the democratic transition in South Africa. University of KwaZulu-Natal Press.

Burrel, V. (2018). Movement-countermovement dynamics and mobilizing the electorate. Mobilization: An International Quarterly, 23(3), 285-305.

Burstein, P., \& Linton, A. (2002). The impact of political parties, interest groups, and social movement organizations on public policy: Some recent evidence and theoretical concerns. Social Forces, $81(2), 380-408$.

Chen, A. S. (2009). The fifth freedom: Jobs, politics and civil rights in the United States, 1941-1972. Princeton University Press.

Chenoweth, E., \& Stephan, M. J. (2011). Why civil resistance works: The strategic logic of nonviolent conflict. Columbia University Press.

Committee to Establish Principles on Renaming. (2016). Letter to President Salovey November 21. http:// president.yale.edu/sites/default/files/files/CEPR_FINAL_12-2-16.pdf,

Crossley, N, and Diani, M. (2018). Networks and fields. In D.A. Snow, S.A. Soule, H. Kriesi, \& H. McCammon, (Eds.), The Wiley-Blackwell companion to social movements, $2^{\text {nd }}$ (pp. 149-166) New York: Wiley \& Sons.

DiMaggio, P., \& Powell, W. (1983). The iron cage revisited: Institutional isomorphism and collective rationality in organizational fields. American Sociological Review, 48, 147-160.

Van Dyke, N., \& Taylor, V. (2019). The cultural outcomes of social movements. In D. A. Snow, S. A. Soule, K. Hanspeter, \& H. McCammon (Eds.), The Wiley-Blackwell companion to social movements, 2nd ed., (pp. 482-498). New York: Wiley \& Sons.

Epstein, S. (1998). Impure science: AIDS, activism, and the politics of knowledge. University of California Press.

Fligstein, N., \& McAdam, D. (2012). A theory of fields. Oxford University Press.

Friedersdorf, C. (2015). The new intolerance of student activism: A fight over Halloween costumes at Yale has devolved into an effort to censor dissenting views. The Atlantic. https://www.theatlantic. 
com/politics/archive/2015/11/the-new-intolerance-of-student-activism-at-yale/414810/. Accessed 2 March 2020.

Gamson, W. A. (1975). The strategy of social protest (2nd ed.). Wadsworth Publishing.

Giugni, M. (1999). Introduction: How social movements matter: Past research, present problems, future developments. In M. Giugni, D. McAdam \& C. Tilly (Eds.) How Social Movements Matter, (pp. xiii-xxxiv). Minneapolis: University of Minnesota Press,

Goldstone, J.A. (1998). Social movements or revolutions?: On the evolution and outcomes of collective action. In G. Marco, D. McAdam, \& C. Tilly (Eds.) From Contention to Democracy. (pp.125-145) Boulder, CO: Rowman and Littlefield.

Goldstone, J. A. (2015). Simplicity vs. complexity. In W. Duyvendak. \& J. Jasper. (Eds.) Breaking down the state: Protestors engaged with authorities (pp. 225-238). Amsterdam: Amsterdam University Press.

Goldstone, J. A. \& Ritter, D. P. (2018). Revolution and social movements. In D. A. Snow, S. Soule, H. Kriesi, \& H. McCammon, (Eds.), The Wiley-Blackwell companion to social movements, $2^{\text {nd }}$ ed., (pp. 682-697) New York: Wiley \& Sons.

Goldstone, J. A. (1980). The weakness of organization. American Journal of Sociology, 85(5), 1017-1042.

Goldstone, J. A. (2004). More social movements or fewer? Beyond political opportunity structures to relational fields. Theory and Society, 33(3-4), 333-365.

Goldstone, J. A. (2014). Revolutions: A very short introduction. Oxford University Press.

Goldstone, J. A., \& Useem, B. (2012). Putting values and institutions back into the theory of strategic action fields. Sociological Theory, 30(1), 37-49.

Greenberg, Z. (2016). Yale drops case over smashed window showing slaves New York Times.

Hartocollis, A. (2017). Long after protests, students shun the university of Missouri New York Times.

Hefferan, J. (2016). Picking up the flag? The University of Missouri football team and whether intercollegiate student athletes may be penalized for exercising their first amendment rights. Depaul Journal of Sports Law and Contemporary Problems, 12(1), 44-74.

Jaschik, S. (2015). Racial Tensions Escalate. Inside Higher Ed. https://www.insidehighered.com/ news/2015/11/09/racial-tensions-escalate-u-missouri-and-yale. Accessed 5 Nov 2020.

Keller, R. (2018). University of Missouri cuts 12 graduate programs amid budget woes. Columbia Daily Tribune.

Kovacs, K. (2015) MU student embarks on hunger strike, demands Wolfe's removal from office Missourian.

Kriesi, H., \& Wisler, D. (1999). The impact of social movements on political institutions: Comparison of the introduction of direct legislation in Switzerland and the United States. In M. Giugni, D. McAdam, \& C. Tilly (Eds.), How Social Movements Matter (pp. 42-65). University of Minnesota Press.

Kronman A. (2019b). Politics by another name. Yale Daily News. https://yaledailynews.com/blog/ 2019/09/04/kronman-politics-by-another-name/. Accessed 7 Nov 2020.

Kronman, A. (2019a). The assault on American excellence. Free Press.

Kucsera, J. and Orfield, G. (2014). New York State's extreme school segregation: inequality, inaction and a damaged future. Los Angeles: UCLA Civil Rights Project.

Liu, M. and Xu, Q. (2016). Charges dropped against Menafee. Yale Daily News.

Luders, J. E. (2010). The civil rights movement and the logic of social change. Cambridge University Press.

Maese, R, \& Babb K. (2015). Missouri football players threaten boycott season amid racial tension Washington Post.

Martin, L. J. (2003). What is field theory? American Journal of Sociology, 109(1), 1-49.

Massey, D. (2016). Residential segregation is the linchpin of racial stratification. City and Community, 15(1), 4-7.

Massey, D., \& Tannen, J. (2015). A research note on trends in black hypersegregation. Demography, 52(3), 1025-1034.

McAdam, D. (1998). On the international origins of domestic political opportunities. In A. N. Costain \& A.S McFarland. (Eds.), Social movements and American political institutions. (pp. 252-267) Lanham: Rowman \& Littlefield.

McAdam, D. (1996). Political opportunities: Conceptual origins, current problems, future directions. In D. McAdam, J. D. McCarthy, \& M. N. Zald (Eds.), Comparative perspectives on social movements (pp. 23-40). Cambridge University Press. 
McAdam, D., \& Boudet, H. (2012). Putting social movements in their place: Explaining opposition to energy projects in the United States, 2000-2005. Cambridge University Press.

McAdam, D., Tarrow, S., \& Tilly, C. (2001). Dynamics of contention. Cambridge University Press.

McManus, D. (2015). Despite recent law and order rhetoric, the old lock 'em up mentality is out of favor with Republicans. Los Angeles Times.

McVeigh, R., Myers, D. J., \& Sikkink, D. (2004). Corn, klansmen, and coolidge: Structure and framing in social movements. Social Forces, 83(2), 653-690.

Mendoza, J. (2015). University of Missouri president resigns amid growing activism, on and off the field. Christian Science Monitor.

Meyer, D. S. (2003). How Social Movements Matter. Contexts Magaine, 2(4), 30-35.

Meyer, D. S. (2004). Protest and political opportunities. Annual Review of Sociology, 30, 125-145.

Meyer, D. S., \& Staggenborg, S. (1996). Movements, countermovements, and the structure of political opportunity. American Journal of Sociology, 101(6), 1628-1660.

Milkman, R. (2017). A new political generation: Millennials and the post-2008 wave of protest. American Sociological Review, 82(1), 1-31.

Moss, D. M., \& Snow, D. A. (2016). Theorizing social movements. In S. Abrutyn (Ed.), Handbook of Contemporary Sociological Theory (pp. 547-569). Springer.

Mottl, T. L. (1980). The analysis of countermovements. Social Problems, 27(5), 620-635.

Naskidashvili, N. (2015). Students march through MU student center in protest of racial injustice Columbia Missourian.

Nepstad, S. (2011). Nonviolent revolutions: Civil resistance in the Late 20th Century. Oxford University Press.

New Haven Register. (2015). Yale University begins open discussion of renaming of Calhoun college.

O'Reilly, M. W., (2016). Naming the problem: Yale Calhoun College needs a new name. Commonweal.

Pedriana, N., \& Stryker, R. (2017). From legal doctrine to social transformation? Comparing U.S. voting rights, equal employment opportunity, and fair housing legislation. American Journal of Sociology., 123(1), 86-135.

Pew Research Center. (2017). Changing attitudes on gay marriage. http://www.pewforum.org/fact-sheet/ changing-attitudes-on-gay-marriage/. Accessed 20 Nov 2020.

Piven, F. F., \& Cloward, R. A. (1977). Poor people's movements: Why they succeed, how they fail. Pantheon Press.

Potash, J. (2014). Hands up, hundreds 'walk out' to demand justice. Yale Daily News.

Rojas, F. and King, B.G. (2018). How social movements interact with organizations and fields: Protest, institutions and beyond. Snow. In D.A. Soule, S.A. Kriesi, \& H. McCammon, (Eds.) The Wiley-Blackwell companion to social movements, $2^{\text {nd }}$ ed., (pp. 203-219) New York: John Wiley \& Sons.

Salovey, P. (2017). Decision on the name of Calhoun College. Office of the President, Yale University. https:// president.yale.edu/speeches-writings/statements/decision-name-calhoun-college/.F. Accessed 5 Nov 2020.

Sawey, E., \& Schrader, K. (2015). Protesters use recruiting day to voice concerns about racism. Columbian Missourian.

Shapiro, E. (2019). Segregation has been the story of New York City's schools for 50 years. New York Times. https://www.nytimes.com/2019/03/26/nyregion/school-segregation-new-york.html?action= click\&module =News\&pgtype $=$ Homepage. Accessed 8 Nov 2020.

Shimer, D., Wang, V. (2015). Students submit new demands to Salovey. Yale Daily News.

Shimer, D., \&Wang, V. (2016a) Months after controversy, Christakises resign Silliman posts. Yale Daily News.

Shimer, D., Wang, V. (2016b). Faculty, scholars call for renaming of Calhoun College. Yale Daily News.

Skocpol, T. (1979). States and social revolutions. Cambridge University Press.

Skrentny, J. D. (2004). The minority rights revolution. Harvard University Press.

Snow, D. A., Lisa, D. M., \& Jones, A. (1998). Disrupting the 'quotidien’: Reconceptualizing the relationship between breakdown and the emergence of collective action. Mobilization: An International Quarterly, 31(1), 1-22.

Snow, D. A., \& Soule, S. A. (2010). A primer on social movements. W.W. Norton.

Stanley-Becker, I. (2015a). A confrontation over race at Yale: hundreds of students demand answers from the school's first black dean. Washington Post.

Stanley-Becker, I. (2015b). Yale's president tells minority students: 'We failed you'. Washington Post. 
Stokes, K. (2018). LA's schools are segregated. LAUSD says there's only so much they can do. LAist. https:// laist.com/2018/07/03/las_schools_are_segregated_lausd_says_theres_only_so_much_they_can_do_ about_it.php. Accessed 5 Dec 2020.

Stone, B. (2015). The anatomy of revolution revisited. Cambridge University Press.

Svrluga, S. (2015). Students accuse Yale SAE fraternity brother of saying 'white girls only' at party door. Washington Post.

Swarts, H. J. (2003). Setting the State's Agenda: Church-Based Community Organizations in American Urban Politics. In J. A. Goldstone (Ed.) States, Parties and Social Movements. (Pp. 78-106). Cambridge: Cambridge University Press.

Swartz, D. (1998). Culture and power: The sociology of Pierre Bourdieu. University of Chicago Press.

Swartz, D. (2013). Symbolic power, politics, and intellectuals: The political sociology of Pierre Bourdieu. University of Chicago Press.

Tarrow, S. (2010). The strategy of paired comparison: Toward a theory of practice. Comparative Political Studies, 43(2), 230-259.

Tarrow, S. (2011). Power in movement: Social movements and contentious politics (3rd ed.). Cambridge University Press.

Tilly, C. (1978). From mobilization to revolution. Addison-Wesley.

Tilly, C. (1999). Conclusion: From interactions to outcomes in social movements. In M. Giugni, D. McAdam, \& C. Tilly (Eds.), How social movements matter (pp. 253-270). Minneapolis.

Tilly, C. (2006). WUNC. In J. T. Schnapp \& M. Tiews (Eds.), Crowds (pp. 289-306). Stanford University Press.

Trachtenberg, B. (2018). The 2015 University of Missouri protests and their lessons for higher education policy and administration. Kentucky Law Journal, 107, 61-121.

University of Missouri System. (2016). Financial Report. https://collaborate.umsystem.edu/sites/controller/ public/Accounting\%20Services/finrpt16.pdf. Accessed 7 Nov 2020.

University of Missouri System. (2018). 2017 Financial Report, p. 27. https://collaborate.umsystem.edu/sites/ controller/public/Accounting\%20Services/finrpt17.pdf. Accessed on 7 November 2020.

Useem, B., \& Goldstone, J. A. (2012). Forging social order and its breakdown: Riot and reform in U.S prisons. American Sociological Review, 67(4), 499-525.

Van Dyke, N., \& Amos, B. (2017). Social movement coalitions: Formation, longevity and success. Sociology Compass, 11(7), 1-17.

Vann, B., Jr. (2018). Movement-countermovement dynamics and mobilizing the electorate. Mobilization: An International Quarterly, 23(3), 285-305.

Wang, M. \& Wang, V. (2015). Students confront Christakis about Halloween email. Yale Daily News.

We the Protestors. (2019). The demands: campus demands. https://www.thedemands.org/consulted. Accessed 7 Nov 2020.

Wouters, R., \& Walgrave, S. (2017). Demonstrating power: How protest persuades political representatives. American Sociological Review, 82, 361-383.

Yaffe-Bellany, D. (2015). Faculty sign letter defending Christakis email. Yale Daily News.

Yale Daily News. 2016. News' view: Our missed opportunity.

Yale Daily News. (2017). Yale to change Calhoun College's name to honor Grace Murray Hopper. https:// news.yale.edu/2017/02/11/yale-change-calhoun-college-s-name-honor-grace-murray-hopper. Accessed on 5 Nov 2020.

Yannielli, J. (2014). Elihu Yale was a slave trader. http://digitalhistories.yctl.org/2014/11/01/ elihu-yale-was-a-slave-trader/

Ye, J. (2015) "Silliman associate master's Halloween email draws ire" Yale Daily News.

Zald, M. N., \& Useem, B. (1987) "Movement and countermovement interaction: Mobilization, tactics and state involvement. In M. N. Zald, \& J. D. McCarthy (Eds.) In Social movement in an organizational society: Collected essays (pp 247-272). New Brunswick, Transaction Publishers

Publisher's note Springer Nature remains neutral with regard to jurisdictional claims in published maps and institutional affiliations. 